\title{
COMPARISON OF EFFICIENCY OF VARIOUS DNA EXTRACTION METHODS FROM CYSTS OF GIARDIA INTESTINALIS MEASURED BY PCR AND TAQMAN ReAl tIME PCR
}

\author{
ADAMSKA M., LEOŃSKA-DUNIEC A., MACIEJEWSKA A., SAWCZUK M. \& SKOTARCZAK B.*
}

Summary: COMPARISON OF EFFICIENCY OF VARIOUS DNA EXTRACTION METHODS FROM GIARDIA INTESTINALIS CYSTS MEASURED BY PCR AND TAQMAN REAL TIME PCR

The aim of the presented study was to work out an effective method of extraction of DNA from Giardia intestinalis cysts as well as a sensitive and specific method for detection of DNA of this protozoan using a polymerase chain reaction (PCR). Twelve protocols for DNA extraction have been compared. Purification and extraction of DNA were preceded by additional actions in order to destroy the cysts' wall. The highest effectiveness of DNA extraction was obtained in case of alternating application of freezing the samples in liquid nitrogen and their incubation in water bath in the temperature of $100{ }^{\circ} \mathrm{C}$, and then the extraction with the QIAamp DNA Tissue Mini Kit (QIAGEN) - T kit - with an all night long incubation with proteinase $\mathrm{K}$ in $56^{\circ} \mathrm{C}$. Effectiveness of DNA extraction with the use of each kit after extraction with each treatment was measured by nested PCR product of $\beta$-giardin gene fragment and $C_{T}$ values of real time PCR of the SSU rRNA gene of $G$. intestinalis. The detection limit, defined as the lowest number detected in $100 \%$ cases, was 100 cysts per $200 \mu$ when effectiveness was evaluated with nested PCR and 50 oocysts with real time PCR after extraction DNA with T kit. Results of our comparative studies have shown that all stages preceding the molecular detection of $G$. intestinalis DNA are equally important, and materially influence on the final effect and this version of method seems to be very useful for the sensitive detection of DNA of $G$. intestinalis.

Keywords: DNA extraction, Giardia intestinalis, PCR, real time PCR.
Résumé : ÉTUDE COMPARATIVE DE L'EFFICACITÉ DE DIFFÉRENTES MÉTHODES D'EXTRACTION D'ADN DE KYSTES DE GIARDIA INTESTINALIS PAR PCR ET PCR EN TEMPS RÉEl (TAQMAN).

Le but de la présente étude est de proposer une méthode d'extraction d'ADN efficace à partir des kystes de Giardia intestinalis et une méthode de détection, à la fois sensible et spécifique, de l'ADN de ce protozaire par PCR. Douze protocoles d'extraction d'ADN ont été comparés. La purification et l'extraction de l'ADN ont été précédées d'étapes visant à détruire la paroi kystique. L'efficacité optimale a été obtenue en alternant la congélation des échantillons dans l'azote liquide et leur incubation dans de l'eau portée à $100^{\circ} \mathrm{C}$, puis par extraction avec le QIAamp DNA Tissue Mini Kit (QIAGEN) - T kit - avec incubation la nuit entière en présence de protéinase $K$ à $56^{\circ} \mathrm{C}$. L'efficacité $d^{\prime}$ extraction obtenue avec chaque kit, selon chaque traitement, a été estimée par observation de l'amplicon du gène de la $\beta$-giardine obtenu par PCR nichée et d'après les valeurs de Ct obtenues par $P C R$ en temps réel avec des amorces amplifiant le gène SSU ARNr de $G$. intestinalis. La limite de détection, définie d'après le plus faible pourcentage de cas détectés était de 100 kystes pour 200 microlitres. Les résultats de nos études comparatives montrent l'égale importance de toutes les étapes précédant la détection moléculaire de l'ADN de $G$. intestinalis et leur influence sur la détection finale, et que cette version méthodologique semble très utile pour une détection sensible de l'ADN de G. intestinalis.

Mots clés : extraction d'ADN, Giardia intestinalis, PCR, PCR en temps réel.

\section{INTRODUCTION}

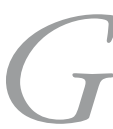
iardia intestinalis, also called Giardia lamblia or Giardia duodenalis, is a protozoan that inhabits in the upper small intestine of humans and several other vertebrates (Graczyk et al., 1998, 2008; Majewska \& Kasprzak, 2000; Adam, 2001; Sprong et al., 2009). This parasite infects thousands of people all over the world and is the cause of giardiasis - acute and chronic manifestations including diarrhea and malabsorption (Adam, 2001; van der Giessen et al., 2006).

\footnotetext{
* Department of Genetics, University of Szczecin, al. Piastów 40b, 71-065 Szczecin, Poland.

Correspondence: Bogumila Skotarczak

E-mail: boskot@univ.szczecin.pl
}

The formation of the cyst allows the parasite to survive outside the host and to resist the adverse conditions (Graczyk et al., 2008; Majewska et al., 2009). Giardia infections are initiated by ingestion of cysts from contaminated food or drinking and recreation water, either by direct fecal-oral contact (Lujan et al., 1997; Graczyk et al., 2008; Monis et al., 2009).

Traditionally, the laboratory diagnosis of intestinal protozoan infections relies on the detection of trophozoites and cysts by microscopic stool examination. However, the majority of diagnostic methods used in the clinical practice have a limited application regarding the detection of protozoans in water samples (Randi et al., 2003; Guy et al., 2003). The most important restriction is much lower concentration of cysts in water in comparison with material collected from patients. In order to improve the monitoring of oocysts of Cryptosporidium in water, 
the United States Environmental Protection Agency (USEPA) introduced the 1622 (USEPA 2001a) Method and then 1623 (USEPA 2001b), used to concentrate and detect the oocysts of Cryptosporidium and cysts of Giardia in water samples. Both methods are used to determine the presence and concentration of the resistant forms in water, and they consist of: filtration, concentration of (oo)cysts, immunomagnetic separation, fluorescent antibody and counter staining, differential interference contrast, microscopic detection and enumeration. These methods do not allow on the identification of Cryptosporidium or Giardia species, as well as the origin of species, or the pathogenic potential of oocysts and cysts. Such data can be obtained with the use of one of the molecular methods based on the nucleic acids isolated from the resistant forms of these parasites, which were obtained with the discussed methods. Because samples of water have only a few Giardia cysts in the presence of many other microorganisms, the recovery of Giardia DNA during DNA extraction is very important (Guy et al., 2003; Skotarczak, 2009). Numerous direct DNA extraction methods have been tested in the preparation of DNA from G. intestinalis cysts, we tried sonication, freezing in liquid nitrogen and boiling in water bath preceding the usage of three commercial kits for the extraction of DNA from $G$. intestinalis cysts (twelve DNA extraction protocols). The effectiveness of DNA extraction was measured with semi-nested PCR signal and $\mathrm{C}_{\mathrm{T}}$ values of TaqMan real time PCR targeting a specific region of rDNA of $G$. intestinalis.

\section{MATERIALS AND METHODS}

$\mathrm{P}$ urified bovine derived preparations of Giardia intestinalis cysts were obtained from Bulk Stock Live, BTF Biomérieux, Australia. Samples containing $7.5 \times 10^{3}$ cysts of $G$. intestinalis with PBS in volume of $1 \mathrm{ml}$ were used for genome DNA extraction. Twelve DNA extraction protocols were investigated successively (Table I). In the protocols 1-3 the DNA extraction was carried out with the use of three kits without any preceding actions. In the protocols 4-12 the extraction with three kits was preceded by different combinations of freeze-thaw or sonication ronds.

The effectiveness of DNA extraction was evaluated with semi-nested PCR and TaqMan real time PCR after

\begin{tabular}{|c|c|}
\hline Protocol 1 & $\begin{array}{l}\text { No treatment - QIAamp DNA Stool Kit (QIAGEN) - St kit; } \\
\text { A. incubation with proteinase } 70^{\circ} \mathrm{C} / 10 \mathrm{~min} \\
\text { B. incubation with proteinase } 56^{\circ} \mathrm{C} / \text { night }\end{array}$ \\
\hline Protocol 2 & $\begin{array}{l}\text { No treatment - QIAamp DNA Tissue Mini Kit (QIAGEN) - T kit ; } \\
\text { A. incubation with proteinase } 56^{\circ} \mathrm{C} / 3 \mathrm{~h} \\
\text { B. incubation with proteinase } 56^{\circ} \mathrm{C} / \text { night }\end{array}$ \\
\hline Protocol 3 & $\begin{array}{l}\text { No treatment - FastDNA SPIN Kit for Soil (MP Biomedicals) - So kit; modified protocol, extraction carried out without } \\
\text { FastPrep Instrument, incubation with proteinase } 56^{\circ} \mathrm{C} / \text { night }\end{array}$ \\
\hline Protocol 4 & $\begin{array}{l}\text { Boiling }\left(100^{\circ} \mathrm{C} / 5 \mathrm{~min}\right) \text { and freezing }\left(-70^{\circ} \mathrm{C} / 5 \mathrm{~min}\right) \text { repeated } 5 \times \text { - QIAamp DNA Stool Kit (QIAGEN) - St kit; } \\
\text { A. incubation with proteinase } 70^{\circ} \mathrm{C} / 10 \mathrm{~min} \\
\text { B. incubation with proteinase } 56^{\circ} \mathrm{C} / \text { night }\end{array}$ \\
\hline Protocol 5 & $\begin{array}{l}\text { Boiling }\left(100{ }^{\circ} \mathrm{C} / 5 \mathrm{~min}\right) \text { and freezing }\left(-70^{\circ} \mathrm{C} / 5 \mathrm{~min}\right) \text { repeated } 5 \times \text { - QIAamp DNA Tissue Mini Kit (QIAGEN) - T kit; } \\
\text { A. incubation with proteinase } 56^{\circ} \mathrm{C} / 3 \mathrm{~h} \\
\text { B. incubation with proteinase } 56^{\circ} \mathrm{C} / \text { night }\end{array}$ \\
\hline Protocol 6 & $\begin{array}{l}\text { Boiling }\left(100^{\circ} \mathrm{C} / 5 \mathrm{~min}\right) \text { and freezing }\left(-70^{\circ} \mathrm{C} / 5 \mathrm{~min}\right) \text { repeated } 5 \times- \text { FastDNA SPIN Kit for Soil (MP Biomedicals) - So kit; } \\
\text { modified protocol, extraction carried out without FastPrep Instrument, incubation with proteinase } 56^{\circ} \mathrm{C} / \mathrm{night}\end{array}$ \\
\hline Protocol 7 & $\begin{array}{l}\text { Boiling }\left(100^{\circ} \mathrm{C} / 2 \mathrm{~min}\right) \text { and freezing in liquid nitrogen }(2 \mathrm{~min}) 3 \times \text { - QIAamp DNA Stool Kit (QIAGEN) - St kit; } \\
\text { A. incubation with proteinase } 70^{\circ} \mathrm{C} / 10 \mathrm{~min} \\
\text { B. incubation with proteinase } 56^{\circ} \mathrm{C} / \text { night }\end{array}$ \\
\hline Protocol 8 & $\begin{array}{l}\text { Boiling }\left(100^{\circ} \mathrm{C} / 2 \mathrm{~min}\right) \text { and freezing in liquid nitrogen }(2 \mathrm{~min}) 3 \times \text { - QIAamp DNA Tissue Mini Kit (QIAGEN) - T kit; } \\
\text { A. incubation with proteinase } 56^{\circ} \mathrm{C} / 3 \mathrm{~h} \\
\text { B. incubation with proteinase } 56^{\circ} \mathrm{C} / \mathrm{night}\end{array}$ \\
\hline Protocol 9 & $\begin{array}{l}\text { Boiling }\left(100^{\circ} \mathrm{C} / 2 \mathrm{~min}\right) \text { and freezing in liquid nitrogen }(2 \mathrm{~min}) 3 \times- \text { FastDNA SPIN Kit for Soil (MP Biomedicals) }- \text { So kit; } \\
\text { modified protocol, extraction carried out without FastPrep Instrument, incubation with proteinase } 56^{\circ} \mathrm{C} / \text { night }\end{array}$ \\
\hline Protocol 10 & $\begin{array}{l}\text { Sonication }(3 \times 2 \mathrm{~min}) \text { - QIAamp DNA Stool Kit (QIAGEN) - St kit; } \\
\text { A. incubation with proteinase } 70^{\circ} \mathrm{C} / 10 \mathrm{~min} \\
\text { B. incubation with proteinase } 56^{\circ} \mathrm{C} / \text { night }\end{array}$ \\
\hline Protocol 11 & $\begin{array}{l}\text { Sonication }(3 \times 2 \text { min) - QIAamp DNA Tissue Mini Kit (QIAGEN) - T kit; } \\
\text { A. incubation with proteinase } 56^{\circ} \mathrm{C} / 3 \mathrm{~h} \\
\text { B. incubation with proteinase } 56^{\circ} \mathrm{C} / \mathrm{night}\end{array}$ \\
\hline Protocol 12 & $\begin{array}{l}\text { Sonication }(3 \times 2 \mathrm{~min}) \text { - FastDNA SPIN Kit for Soil (MP Biomedicals) - So kit; modified protocol, extraction carried out } \\
\text { without FastPrep Instrument, incubation with proteinase } 56^{\circ} \mathrm{C} / \text { night }\end{array}$ \\
\hline
\end{tabular}

Table I. - DNA extraction protocols. 
extraction with each preisolation treatment. For the determination of the detection limit samples containing $7.5 \times 10^{3}$ cysts of $G$. intestinalis were diluted in distilled water to $1 \times 10^{3}, 5 \times 10^{2}, 1 \times 10^{2}, 5 \times 10^{1}$ and $1 \times 10^{1}$ cysts per $200 \mu \mathrm{l}$. These dilutions are approximate, because the cysts were not counted.

\section{SEMI-NESTED PCR AMPLIFICATION}

A highly polymorphic region of the $\beta$-giardin gene was amplified by semi-nested PCR protocol (Caccio et al., 2002). The method involves the amplification of an approximately $753 \mathrm{bp}$-long primary product followed by a secondary reaction of an internal fragment with a length of approximately $384 \mathrm{bp}$. For the I. PCR step, a PCR product was amplified by using primers G7 5'-AAGCCCGACGACCTCACCCGCAGTGC-3' and G759 5'-GAGGCCGCCCTGGATCTTCGAGACGAC-3' (Caccio et al., 2002). For the II PCR step, a PCR product was amplified by using primers G376 5'-CATAACGACGCCATCGCGGCTCTCAGGAA-3' and G7595'GAGGCCGCCCTGGATCTTCGAGACGAC-3' (Caccio et al. 2002). Each PCR mixture (total volume, $10 \mu \mathrm{l}$ ) contained $1 \mu \mathrm{l}$ of Sigma (USA) $10 \times$ PCR buffer, $30 \mathrm{mM}$ $\mathrm{MgCl}_{2}, 0.3 \mathrm{nM}$ of each deoxynucleotide triphosphate, $5 \mathrm{pM}$ of each primer, $0.5 \mathrm{U}$ of Taq polymerase Sigma (USA), and $1 \mu \mathrm{l}$ of DNA template. The reactions were performed in a DNA thermal cycler (Biometra, Germany and MJ Research, USA). Thermal-time profiles in first and second PCR were the same as described by Castro-Hermida et al. (2008). Negative control reaction mixtures contained sterile distilled water in place of template DNA. PCR products were visualized by $1.5 \%$ agarose gel electrophoresis.

\section{TAQMAN REAL TIME PCR}

A region of the small subunit rRNA gene of $G$. intestinalis was used as a target sequence for real time PCR. Primers Gd-80F and Gd-127R amplifying a 62-bp fragment (Haque et al., 2007) were used. The PCR samples (volume $10 \mu \mathrm{l}$ ) contained $14 \mathrm{pM}$ of each primers, $8 \mathrm{pM}$ of the probe Gd-FT (Genomed, Poland), $0.5 \mathrm{nM}$ of each dNTP (Novazym, Poland), $15 \mathrm{mM} \mathrm{MgCl}$, $1.5 \mathrm{U}$ Taq DNA Polymerase (Sigma, USA) and $2 \mu$ of DNA template. Reactions were performed in Rotor Gene 6000 (Corbett, Australia). Oligonuceotides sequences and thermal profile were performed as described previously (Haque et al., 2007) with modification of cycles' number ( 65 cycles). The threshold cycle $\left(\mathrm{C}_{\mathrm{T}}\right)$ was calculated for individual samples by the internal software of the cycler using the manual threshold setting at a fluorescence value of $10^{-1.75}$. Appropriate negative controls were included in each PCR run. All analysis were carried out in four replicates. TaqMan real time PCR reaction was developed to show reproducible PCR efficiency values with regard to all samples preceded by different protocols.

\section{RESULTS}

omparison of efficiency of various G. intestinalis undiluted cyst treatments prior to DNA extraction with the use of twelve protocols, measured with semi-nested PCR signal and $\mathrm{C}_{\mathrm{T}}$ values of real time PCR have shown that the best results were obtained after extraction of DNA with $\mathrm{T}$ kit, preceded with triple liquid nitrogen/water bath in $100{ }^{\circ} \mathrm{C}$ for 2 minutes and with proteinase $\mathrm{K}$ digestion all night long (protocol $8 \mathrm{~B}$, Table II).

The assessment of sensitivity was determined using the analysis of five different diluted suspensions (Table III) of $G$. intestinalis cysts in four replicates each. The detection limit, defined as the lowest number detected in $100 \%$ cases, was 100 cysts per $200 \mu \mathrm{l}$ when effectiveness was evaluated with PCR and 50 cysts with real time PCR after extraction of DNA with T kit. Whereas the detection limit after DNA extraction with two other kits was significantly higher (100 - for St kit and 1000 for So kit measured by real-time PCR) (Table III; Figs 1, 2).

\begin{tabular}{|c|c|c|c|}
\hline \multicolumn{2}{|c|}{$\begin{array}{l}\text { DNA extraction } \\
\text { protocols }\end{array}$} & \multirow{2}{*}{$\begin{array}{c}\begin{array}{c}\text { Results of semi- } \\
\text { nested PCR }\end{array} \\
-\end{array}$} & \multirow{2}{*}{$\begin{array}{c}\begin{array}{c}\text { Results of Taqman } \\
\text { RealTime PCR }\end{array} \\
\left.\text { (threshold cycle - C } C_{T}\right) \\
-\end{array}$} \\
\hline & A & & \\
\hline Protocol 1 & $\mathrm{~B}$ & - & - \\
\hline \multirow{2}{*}{ Protocol 2} & A & - & - \\
\hline & $\mathrm{B}$ & - & - \\
\hline Protocol 3 & - & - & - \\
\hline \multirow{2}{*}{ Protocol 4} & A & - & - \\
\hline & $\mathrm{B}$ & - & - \\
\hline \multirow{2}{*}{ Protocol 5} & A & - & - \\
\hline & $\mathrm{B}$ & - & - \\
\hline Protocol 6 & - & - & - \\
\hline \multirow{2}{*}{ Protocol 7} & A & - & $52.8 \pm 0.56$ \\
\hline & B & ++++ & $15.2 \pm 0.82$ \\
\hline \multirow{2}{*}{ Protocol 8} & $\mathrm{~A}$ & - & $48.4 \pm 0.25$ \\
\hline & $\mathrm{B}$ & ++++ & $13.5 \pm 0.78$ \\
\hline Protocol 9 & - & - & $49.7 \pm 0.48$ \\
\hline \multirow{2}{*}{ Protocol 10} & $\mathrm{~A}$ & - & - \\
\hline & $\mathrm{B}$ & +++ & $21.8 \pm 0.42$ \\
\hline \multirow[b]{2}{*}{ Protocol 11} & A & - & $53.8 \pm 0.66$ \\
\hline & B & +++ & $18.9 \pm 0.73$ \\
\hline Protocol 12 & - & - & $54.8 \pm 0.35$ \\
\hline
\end{tabular}

++++ very strong intensity of the DNA band as determined by ethidium bromide stained-agarose gel electrophoresis; +++ strong intensity of the DNA band; + + medium intensity of the DNA band; + , weak intensity of the DNA band; - no DNA band visualized on ethidium bromide stained-agarose gel electrophoresis.

Table II. - Comparative efficiency of various G. intestinalis cysts undiluted treatments prior to DNA extraction with the use of twelve protocols, measured with PCR signal of product of the $\beta$-giardin gene and Treshold cycle $\left(\mathrm{C}_{\mathrm{T}}\right)$ of real time PCR (18S rRNA gene). 


\begin{tabular}{|c|c|c|c|c|c|c|c|c|c|c|}
\hline \multirow{3}{*}{$\begin{array}{c}\text { DNA } \\
\text { extraction } \\
\text { protocols }\end{array}$} & \multicolumn{5}{|c|}{ Results of semi-nested PCR ${ }^{1}$} & \multicolumn{5}{|c|}{$\begin{array}{c}\text { Results of TaqMan real time PCR } \\
\text { (threshold cycle }-\mathrm{C}_{\mathrm{T}} \text { ) }\end{array}$} \\
\hline & \multicolumn{5}{|c|}{ Number of cysts } & \multicolumn{5}{|c|}{ Number of cysts } \\
\hline & $1 \times 10^{3}$ & $5 \times 10^{2}$ & $1 \times 10^{2}$ & $5 \times 10^{1}$ & $1 \times 10^{1}$ & $1 \times 10^{3}$ & $5 \times 10^{2}$ & $1 \times 10^{2}$ & $5 \times 10^{1}$ & $1 \times 10^{1}$ \\
\hline $7 \mathrm{~B}$ & ++ & + & - & - & - & $26.2 \pm 0.18$ & $28.4 \pm 0.52$ & $33.7 \pm 0.48$ & $41.4 \pm 0.16$ & - \\
\hline $8 \mathrm{~B}$ & +++ & ++ & +++ & ++ & - & $21.5 \pm 0.93$ & $25.9 \pm 0.38$ & $28.9 \pm 0.41$ & $33.8 \pm 0.53$ & $48.2 \pm 0.82$ \\
\hline 9 & - & - & - & - & - & $43.8 \pm 0.29$ & $49.5 \pm 0.38$ & & & \\
\hline
\end{tabular}

+++ strong intensity of the DNA band; ++ medium intensity of the DNA band; + weak intensity of the DNA band; - no DNA band visualized on ethidium bromide stained-agarose gel electrophoresis.

Table III. - The detection level of G. intestinalis cysts in water suspensions defined by semi-nested PCR signal and threshold cycle $\left(\mathrm{C}_{\mathrm{T}}\right)$ of real time PCR with the use of three protocols (7 B, 8 B, 9). Data represent mean $+/$ - standard deviation for positive samples.

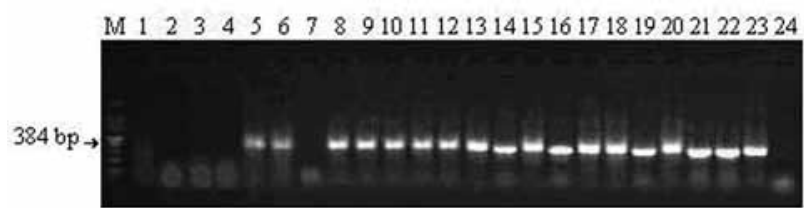

Fig. 1. - Products of amplification of gene fragment encoding $\beta$-giardin of $G$. intestinalis obtained from DNA isolated with protocol $8 \mathrm{~B}(3 \mathrm{x}$ boiling $\left(100{ }^{\circ} \mathrm{C} / 2 \mathrm{~min}\right)$ and freezing in liquid nitrogen $(2 \mathrm{~min})$, QIAamp DNA Tissue Mini Kit, QIAGEN, incubation with proteinase $56^{\circ} \mathrm{C} /$ night)

M - marker of molecular masses; paths 1-4 - amplicons obtained from DNA isolate received from 10 cysts; paths 5-8 - amplicons obtained from DNA isolate received from 50 cysts; paths 9-12 amplicons obtained from DNA isolate received from 100 cysts; paths 13-16 - amplicons obtained from DNA isolate received from 500 cysts; paths 17-20 - amplicons obtained from DNA isolate received from 1,000 cysts; paths 21, 22 and 23 - amplicons obtained from positive controls; path 24 - negative control

\section{DISCUSSION}

Gris iardia intestinalis (G. duodenalis or G. lamblia) is a common protozoan parasite that infects a wide range of mammalian hosts. In humans it is one of the most frequently identified protozoan parasites causing gastrointestinal disease worldwide (Olson et al., 2004; Caccio et al., 2005). Light microscopy or immunofluorescence assay has been used to identify G. intestinalis in most laboratories. However, these techniques might not be sensitive enough to detect cysts in environmental samples (Rochelle et al., 1997; Haque et al., 2007). Recently, a few PCR-based techniques have been developed for detection and genotypic characterization of G. intestinalis (Yong et al., 2002; Muller et al., 2008 ; Ajjampur et al., 2009 ; Tashima et al., 2009). In water samples $G$. intestinalis cysts occur in very low concentration (Kaucner \& Stinear, 1998), so the recovery of this pathogen DNA during DNA extraction becomes important.

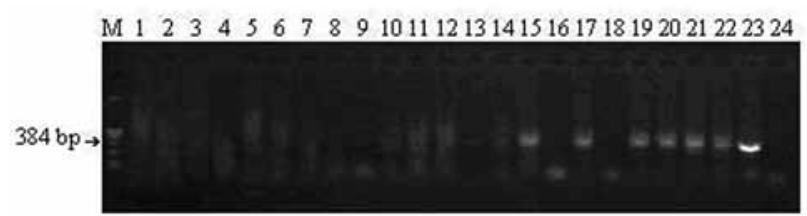

Fig. 2. - Products of amplification of gene fragment encoding $\beta$-giardin of $G$. intestinalis obtained from DNA isolated with protocol $7 \mathrm{~B}\left(3 \mathrm{x}\right.$ boiling $\left(100^{\circ} \mathrm{C} / 2 \mathrm{~min}\right)$ and freezing in liquid nitrogen (2 min), QIAamp DNA Stool Kit, QIAGEN, incubation with proteinase $56^{\circ} \mathrm{C} /$ night)

M - marker of molecular masses; paths 1-4 - amplicons obtained from DNA isolate received from 10 cysts; paths 5-8 - amplicons obtained from DNA isolate received from 50 cysts; paths 9-12 amplicons obtained from DNA isolate received from 100 cysts; paths 13-16 - amplicons obtained from DNA isolate received from 500 cysts; paths 17-20 - amplicons obtained from DNA isolate received from 1,000 cysts; paths 21, 22 and 23 - amplicons obtained from positive controls; path 24 - negative control.

There is not much data in the available literature relevant to initial treatment of cysts before the DNA extraction (Mahbubani et al., 1991; Sulaiman et al., 2004) despite the Giardia cysts are characterized with high resistance on externals influence (Carranza et al., 2002; Sunderland et al., 2007). Cryptosporidium oocysts have similar features, because before the DNA extraction they are subjected to different actions in order to destroy their wall (Sluter et al., 1997; Harris \& Petry, 1999; Jiang et al., 2005). Giardia cysts are oval in shape and range in size from 6 to $10 \mu \mathrm{m}$. The cyst wall varies from 0.3 to $0.5 \mu \mathrm{m}$ in thickness that is formed by an outer filamentous layer and an inner membranous layer including two membranes that enclose the periplasmic space (Adam, 2001). The biochemical composition of the cyst wall is composed of carbohydrates, in the form of $\mathrm{N}$-acetyl galactosamine polymers (Lujan et al., 1997), and cyst wall proteins (CWPs) (Lujan et al., 1995 ; Sun et al., 2003). The presented studies have shown that the extraction of DNA from Giardia cysts not preceded with any actions that could destroy the cyst wall is not 


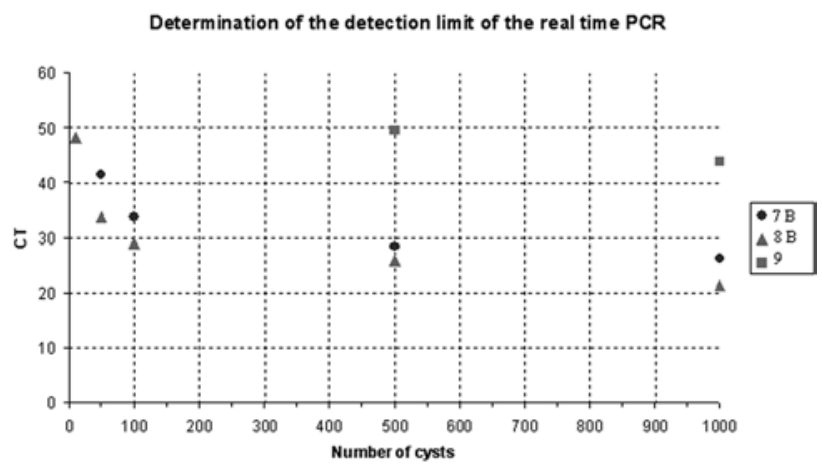

Fig. 3. - Determination of the DNA-based detection limit of the realtime PCR after three protocols: $7 \mathrm{~B}\left(3 \mathrm{x}\right.$ boiling $\left(100{ }^{\circ} \mathrm{C} / 2 \mathrm{~min}\right)$ and freezing in liquid nitrogen (2 min), QIAamp DNA Stool Kit, QIAGEN, incubation with proteinase $56^{\circ} \mathrm{C} /$ night), $8 \mathrm{~B}$ (boiling $-100{ }^{\circ} \mathrm{C} / 2 \mathrm{~min}$ - and freezing in liquid nitrogen - 3x/2 min, QIAamp DNA Tissue Mini Kit, QIAGEN, incubation with proteinase $56^{\circ} \mathrm{C} /$ night), 9 (boiling $-100^{\circ} \mathrm{C} / 2 \mathrm{~min}$ - and freezing in liquid nitrogen - $3 \mathrm{x} / 2 \mathrm{~min}$ - FastDNA SPIN Kit for Soil, MP Biomedicals; modified protocol. Average of triplicate thresholds cycle (CT) values are presented. Standard deviation was too small to be depicted.

effective (protocols 1-3) (Table II). Effectiveness of DNA extraction with the use of each kit after extraction with each treatment was measured by semi-nested PCR product of $\beta$-giardin gene fragment and $\mathrm{C}_{\mathrm{T}}$ values of real time PCR of the SSU rRNA gene of $G$. intestinalis. The $\beta$-giardin gene is considered unique to Giardia spp., effectively eliminating the chance of crossamplification of host or other no target templates (Caccio et al., 2002). Gene encoding $18 \mathrm{~S}$ rRNA is often used as a genetic marker for the detection of $G$. intestinalis because of the possibility of designing primers complementary to its sequences, specific only for this species (Rochelle et al., 1997; Haque et al., 2007, Nantavisai et al., 2007; Castro-Hermida et al., 2008).

Comparison of efficiency of various $G$. intestinalis undiluted cysts treatments prior to DNA extraction with the use of three kits have shown that the best results were obtained after extraction of DNA with QIAamp DNA Tissue Mini Kit ( $\mathrm{T}$ kit), preceded with triple liquid nitrogen/water bath in $100{ }^{\circ} \mathrm{C}$ for 2 minutes and with proteinase $\mathrm{K}$ digestion all night long (protocol $8 \mathrm{~B}$ ). The alternating application of boiling and freezing in the temperature of $-70{ }^{\circ} \mathrm{C}$ before the extraction did not cause the destruction of cysts cell wall and the extraction occurred to be not effective (protocols 4-6), whereas sonication gave satisfactory results (protocols 10-12) but worse than in case of applying the alternating boiling and freezing in liquid nitrogen (protocols 7-9) (Table II). Besides, the usage of liquid nitrogen enabled to prepare more number of samples dependent on the capacity of container in which they were frozen, whereas the appliance for sonication allowed to subject to ultrasounds only single samples what lengthened the time of preparing samples for DNA extraction. Time of treatment with proteinase $\mathrm{K}$ was also very important, only the all night long incubation guaranteed the effective extraction of DNA from Giardia cysts (Table II). The extraction of DNA from undiluted solution including Giardia cysts with $\mathrm{T}$ kit and St kit occurred to be equally effective (protocols $7 \mathrm{~B}$ and $8 \mathrm{~B}$ ) (Table II), but isolation from smaller number of cysts was more effective in case of using T kit (protocol 8 B) (Table III). It may result from fact that St kit is designed for isolation of DNA from stool and cysts present in water environment may be partly removed with pollutions and inhibitors. So kit occurred to be completely ineffective, but it was used without a FastPrep Instrument recommended by producer, which is an integral part of the kit because of its high price. Similar trials were carried out earlier in order to extract the DNA from oocysts of C.parvum and the effects were very similar to those in case of $G$. intestinalis (Adamska et al., 2010). The detection limit, defined as the lowest numbers detected in $100 \%$ cases, was 100 cysts per $200 \mu \mathrm{l}$ when effectiveness was evaluated with nested PCR and 50 oocysts with real time PCR after extraction DNA with T kit (Table III). We used small number of cysts, so the extraction efficiency can be lower and detection limit can be smaller than in case of using large number of cysts.

When higher sensitivity of PCR is required, nested PCR is often used, which involves two reactions. The product of the first reaction is used as a template for the second reaction. In this way, all irregularities should take place in the first reaction. The second one, starting amplification from a reasonably high amount of the template should be already fully effective. Sensitivity of detection of $G$. intestinalis has been further improved by using nested PCR (Caccio et al., 2002). Unfortunately, conventional nested PCR is not very suitable for routine diagnostics usage because of the risk of contamination by short amplified DNA fragments (Abravaya et al., 1997). That risk may be eliminated by applying the real time PCR. In the presented work, we have applied a TaqMan real time PCR protocol for sensitive detection of $G$. intestinalis, which development was carried out by Haque et al. (2007). Thus, PCR can be monitored continuously, in closed tubes, without the need of any subsequent, discontinuous analysis and without electrophoresis. This version of method seems to be very useful for the sensitive detection of DNA of G. intestinalis, especially when our studies have shown that TaqMan real time PCR method characterizes with higher sensitivity than typical PCR reaction (Table III). Results of our comparative studies have shown that all stages preceding the molecular detection of $G$. intestinalis are equally important and materially influence on the final effect. 


\section{ACKNOWLEDGEMENTS}

his study was supported in part by the Ministry of Science and Higher Education, grant no. N N404 248635.

\section{REFERENCES}

Abravaya K., Hu H.Y. \& Khalil O. Strategies to avoid amplicon contamination, in: Nucleic acid amplification technologies: Application to disease diagnosis. Lee H., Morse S. \& Olsvik O. (eds), Cambridge, MA, Birkhäuser Boston, 1997, 125-133.

ADAm R.D. Biology of Giardia lamblia. Clinical Microbiology Reviews, 2001, 14, 447-475.

Adamska M., Leońska-Duniec A., Maciejewska A., Sawczuk M. \& SKOTARCZAK B. PCR and real time PCR for the DNA detection of oocysts of Cryptosporidium parvum. Folia biologica (Cracow), in press.

AjJampur S.S., Sankaran P., Kannan A., Sathyakumar K., Sarkar R., Gladstone B.P. \& Kang G. Giardia duodenalis assemblages associated with diarrhea in children in South India identified by PCR-RFLP. American Journal of Tropical Medicine and Hygiene, 2009, 80 (1), 16-19.

Cacciò S.M., De Giacomo M. \& Pozio E. Sequence analysis of the beta-giardin gene and development of a polymerase chain reaction-restriction fragment length polymorphism assay to genotype Giardia duodenalis cysts from human faecal samples. International Journal of Parasitology, 2002, 32 (8), 1023-1030.

CaCciò S.M., ThOmpson R.C., McLauchlin J. \& SMith H.V. Unraveling Cryptosporidium and Giardia epidemiology. Trends in Parasitology, 2005, 21 (9), 430-437.

Carranza P.G., Feltes G., Ropolo A., Quintana S.M., Touz M.C. \& LUJÁN H.D. Simultaneous expression of different variantspecific surface proteins in single Giardia lamblia trophozoites during encystation. Infection and Immunity, 2002, 70 (9), 5265-5268.

Castro-Hermida J.A., García-Presedo I., Almeida A., GonzálezWarleta M., Correia Da Costa J.M. \& Mezo M. Presence of Cryptosporidium spp. and Giardia duodenalis through drinking water. Science of the Total Environment, 2008, 405 (1-3), 45-53.

Graczyk T.K., Fayer R., Trout J.M., Lewis E.J., Farley C.A., Sulaiman I. \& Lal A.A. Giardia sp. and infectious Cryptosporidium parvum oocysts in the feces of migratory Canada geese (Branta canadensis). Applied and Environmental Microbiology 1998, 64, 2736-2738.

Graczyk T.K., Majewska A.C. \& Schwab K.J. The role of birds in dissemination of human waterborne enteropathogens. Trends in Parasitology, 2008, 24, 55-59.

Guy R.A., Payment P., Krull U.J. \& Horgen P.A. Real-Time PCR for quantification of Giardia and Cryptosporidium in environmental water samples and sewage. Applied and Environmental Microbiology, 2003, 69 (9), 5178-5185.
Haque R., Roy S., Siddique A., Mondal U., Rahman S.M., Mondal D., Houpt E. \& Petri W.A. JR. Multiplex real-time PCR assay for detection of Entamoeba histolytica, Giardia intestinalis, and Cryptosporidium spp. American Journal of Tropical Medicine and Hygiene, 2007, 76 (4), 713-717.

HARRIS J.R. \& PETRY F. Cryptosporidium parvum: structural components of the oocyst wall. Journal of Parasitology, 1999, 85 (5), 839-849.

Jiang J., Alderisio K.A., Singh A. \& XiaO L. Development of procedures for direct extraction of Cryptosporidium DNA from water concentrates and for relief of PCR inhibitors. Applied and Environmental Microbiology, 2005, 71 (3), 1135-1141.

KAUCNER C. \& STINEAR T. Sensitive and rapid detection of viable Giardia cysts and Cryptosporidium parvum oocysts in largevolume water samples with wound fiberglass cartridge filters and reverse transcription-PCR. Applied and Environmental Microbiology, 1998, 64 (11), 4627.

Lujan H.D., MowatT M.R., Conrad J.T., Bowers B. \& Nash T.E. Identification of a novel Giardia lamblia cyst wall protein with leucine-rich repeats. Implications for secretory granule formation and protein assembly into the cyst wall. Journal of Biological Chemistry, 1995, 270, 29307-29313.

LuJan H.D., MowatT M.R. \& NaSh T.E. Mechanisms of Giardia lamblia differentiation into cysts. Microbiology and Molecular Biology Review, 1997, 61, 294-304.

Mahbubani M.H., Bej A.K., Perlin M., Schaefer F.W. $3^{\text {RD }}$, JAKUBOwsKI W. \& ATlas R.M. Detection of Giardia cysts by using the polymerase chain reaction and distinguishing live from dead cysts. Applied and Environmental Microbiology, 1991, 57 (12), 3456-3461.

MajeWsKa A.C. \& KasprZAK W. New axenic isolates of Giardia from primates. Acta Parasitologica, 2000, 45, 55-56.

Majewska A.C., Graczyk T.K., SŁodKowicz-Kowalska A., Tomang L., JęDrzejewski S., Zduniak P., Solarczyk P., Nowosad A. \& NowOSAD P. The role of free-ranging, captive, and domestic birds of Western Poland in environmental contamination with Cryptosporidium parvum oocysts and Giardia lamblia cysts. Parasitology Research, 2009, 104 (5), 1093-1099.

Monis P.T., CACCIO S.M. \& ThOmpson R.C. Variation in Giardia: towards a taxonomic revision of the genus. Trends in Parasitology, 2009, 25 (2), 93-100.

Muller J., Ley S., Felger I., Hemphill A. \& Muller N. Identification of differentially expressed genes in a Giardia lamblia WB C6 clone resistant to nitazoxanide and metronidazole. Journal of Antimicrobial Chemotherapy, 2008, 62, 72-82.

Nantavisai K., Mungthin M., Tan-ariya P., Rangsin R., NaAglor T. \& LeElayoova S. Evaluation of the sensitivities of DNA extraction and PCR methods for detection of Giardia duodenalis in stool specimens. Journal of Clinical Microbiology, 2007, 45 (2), 581-583.

Olson M.E., O'Handley R.M., Ralston B.J., McAllister T.A. \& ThOMpson R.C. Update on Cryptosporidium and Giardia infections in cattle. Trends in Parasitology, 2004, 20 (4), 185-191.

Randi M., McCuin R.M. \& Clancy L. Modifications to United States Environmental Protection Agency methods 1622 and 1623 for detection of Cryptosporidium oocysts and Giardia 
cysts in water. Applied and Environmental Microbiology, 2003, 69, 267-274.

Rochelle P.A., De Leon R., Stewart M.H. \& Wolfe R.L. Comparison of primers and optimization of PCR conditions for detection of Cryptosporidium parvum and Giardia lamblia in water. Applied and Environmental Microbiology, 1997, 63 (1), 106-114.

SKOTARCZAK B. Methods for parasitic protozoans detection in the environmental samples. Parasite, 2009, 16, 1-8.

SLuTER S.D., TzIPORI S. \& Widmer G. Parameters affecting polymerase chain reaction detection of waterborne Cryptosporidium parvum oocysts. Applied Microbiology and Biotechnology, 1997, 48 (3), 325-330.

SPRONG H., CACCIÒ S.M. \& VAN DER GIESSEN J.W. Identification of zoonotic genotypes of Giardia duodenalis. PLoS Neglected Tropical Diseases, 2009, 3 (12), 558.

Sunderland D., GraczyK T.K., TAmang L. \& Breysse P.N. Impact of bathers on levels of Cryptosporidium parvum oocysts and Giardia lamblia cysts in recreational beach waters. Water Research, 2007, 41 (15), 3483-3489.

Sulaiman I. M., Jiang J., Singh A. \& XiaO L. Distribution of Giardia duodenalis genotypes and subgenotypes in raw urban wastewater in Milwaukee, Wisconsin. Applied and Environmental Microbiology, 2004, 70, 3776-3780.

Sun C.H., McCaffery J.M., Reiner D.S. \& Gildin F.D. Mining the Giardia lamblia genome for new cyst wall proteins. Journal of Biological Chemistry, 2003, 278, 21701-21708.

Tashima N.T., Simões M.J., Leite C.Q., Fluminhan A., Nogueira M.A. \& Malaspina A.C. Classic and molecular study of Giardia duodenalis in children from a daycare center in the region of Presidente Prudente, São Paulo, Brazil. Revista do Instituto de Medicina Tropical de São Paulo, 2009, 51 (1), 19-24.

U.S. Environmental Protection Agency. Method 1622Cryptosporidium and Giardia in water by filtration/IMS/ FA. U.S. Environmental Protection Agency publication no. 821/R-01-026. U.S. Environmental Protection Agency, Washington, D.C, 2001.

U.S. Environmental Protection Agency. Method 1623Cryptosporidium and Giardia in water by filtration/IMS/ FA. U.S. Environmental Protection Agency publication no. 821/R-01-025. U.S. Environmental Protection Agency, Washington, D.C., 2001.

VAn der Giessen J.W., DE VRIes A., Roos M., Wielinga P., KortBeEK L.M. \& MANK T.G. Genotyping of Giardia in Dutch patients and animals: a phylogenetic analysis of human and animal isolates. International Journal of Parasitology, 2006, 36, 849-858.

Yong T., Han K., YANG H. \& PARK S. PCR-RFLP analysis of Giardia intestinalis using a Giardia-specific gene, GLORFC4. Parasite, 2002, 9 (1), 65-70.

Reçu le 15 avril 2010 Accepté le 7 juillet 2010 